Article

\title{
Development of efficient solid chiral catalysts with designable linkage for asymmetric transfer hydrogenation of quinoline derivatives
}

\author{
Yiqi Ren a,b, Lin Tao a,b, Chunzhi Li ${ }^{\text {a,b }}$, Sanjeevi Jayakumara, He Li a , Qihua Yang a,* \\ a State Key Laboratory of Catalysis, Dalian Institute of Chemical Physics, Chinese Academy of Sciences, Dalian 116023, Liaoning, China \\ b University of Chinese Academy of Sciences, Beijing 100049, China
}

\section{A R T I C L E I N F O}

\section{Article history:}

Received 18 December 2020

Accepted 18 January 2021

Available online 5 May 2021

\section{Keywords:}

Heterogeneous asymmetric catalysis

Asymmetric transfer hydrogenation

Quinolines

Imidazolate

Ionic liquid

$N$-(p-toluenesulfonyl)-1,2-

diphenylethylenediamine

\begin{abstract}
A B S T R A C T
Developing chiral solid catalysts for asymmetric catalysis is desirable for the elimination of homogeneous catalysis flaws but remains an immense challenge. Herein, we report the immobilization of TSDPEN on SBA-15 with an ionic liquid (IL) linkage via the one-pot reaction of imidazole-TsDPEN- $N$-Boc with 3-(trimethoxysilyl)propyl bromide in the SBA-15 mesopores. After coordination to Rh, the chiral solid catalysts could efficiently catalyze quinoline transfer hydrogenation, achieving $97 \%$ conversion with $93 \%$ ee, which was comparable to their homogeneous counterparts. The chiral solid catalyst with the IL linkage afforded much higher turnover frequency than that without the IL linkage ( $\left.93 \mathrm{~h}^{-1} v s .33 \mathrm{~h}^{-1}\right)$, attributed to the phase transfer and formate-enriching ability of the IL linkage. Furthermore, the effect of the $\mathrm{pH}$ on the reaction rate of the solid catalyst was investigated, preventing reaction rate retardation during the catalytic process. The tuning of the linkage group is an efficient approach for catalytic activity improvement of immobilized chiral catalysts.
\end{abstract}

(C) 2021, Dalian Institute of Chemical Physics, Chinese Academy of Sciences. Published by Elsevier B.V. All rights reserved.

\section{Introduction}

Chiral 1,2,3,4-tetrahydroquinolines are important building blocks of biological medicines and natural products [1,2]. Therefore, considerable attention has been devoted to their synthesis [1-4]. Until now, the asymmetric reduction of prochiral quinolines has been among the most convenient approaches for chiral tetrahydroquinoline synthesis. This involves asymmetric hydrogenation $(\mathrm{AH})$ with $\mathrm{H}_{2}$ as the reductant [5-7] or asymmetric transfer hydrogenation (ATH) using, e.g., Hantzsch esters or formates as reducing agents [8-12]. In comparison with asymmetric hydrogenation, ATH does not require high-pressure hydrogen gas and a sophisticated pressure vessel [13].

The first quinoline ATH was reported by Rueping and coworkers, with a binol-derived chiral Brønsted acid as the catalyst [8]. Using a Hantzsch ester as the hydrogen source, 2-aryl-substituted quinolines were reduced with excellent enantioselectivity, but an enantioselectivity decrease was observed for some 2-alkyl-substituted substrates. Besides the chiral Brønsted acid-based organocatalysts, organometallic catalysts were also used in quinoline ATH. The Zhou's group reported quinoline ATH with $[\operatorname{Ir}(\mathrm{COD}) \mathrm{Cl}]_{2} /(S)-\mathrm{SegPhos} / \mathrm{I}_{2}$ as the catalyst in the presence of a Hantzsch ester [9]. Noyori-type

\footnotetext{
* Corresponding author. Tel: +86-411-84379552; Fax: +86-411-84694447; E-mail: yangqh@dicp.ac.cn

This work was supported by the National Key R\&D Program of China (2017YFB0702800), the National Natural Science Foundation of China (21733009, 21972134) and the Strategic Priority Research Program of the Chinese Academy of Sciences (XDB17020200).

DOI: 10.1016/S1872-2067(20)63764-0 | http://www.sciencedirect.com/journal/chinese-journal-of-catalysis | Chin. J. Catal., Vol. 42, No. 9, September 2021
} 
TsDPEN-Rh complexes were reported by the Xiao's group for quinoline ATH [10] with sodium formate or $\mathrm{HCOOH} /$ triethylamine azeotrope as reductants [11]. In terms of expensive chiral catalyst recycling, and facile purification and product isolation, heterogeneous ATH is more advantageous than the homogeneous one [14-16].

Previously, TsDPEN-Ru complexes have been immobilized on mesoporous silicas for aromatic ketone ATH, using sodium formate as the hydrogen source [17-20]. Considering the co-existence of oil substrates, solid catalysts, and sodium formate aqueous solution within the reaction system, mass diffusion is a major problem during aromatic ketone ATH. The ATH of quinolines and their derivatives faces similar diffusion problems because quinolines also have low water solubility. To enhance the ATH catalytic activity with sodium formate as the reducing reagent, the solid catalysts need to enable the fast enrichment of both the organic substrates and formate anions. In previous reports, the TsDPEN ligand was immobilized on silica, primarily through alkane linkage, using $(1 R, 2 R)$ 4-((trimethoxysilyl)ethyl)phenylsulfonyl-1,2-diphenylethylene diamine (Scheme 1). Generally, surface modification of the solid chiral catalysts with a phase transfer agent is required to promote activity within the tri-phase reaction system $[20,21]$. This is not only tedious but may also block the chiral active sites. Herein, with the aim of synthesizing a solid chiral catalyst with both chiral active sites and enrichment sites for organic substrates and formate anions, the TsDPEN ligands were immobilized on mesoporous silicas via ionic liquid (IL) linkage by a one-pot method (Scheme 1). The IL linkage close to the chiral active site could aid formate anion and organic substrate enrichment. In quinoline ATH, the solid chiral catalyst with the IL linkage is more active and enantioselective than that with the alkane linkage. The key parameters influencing the solid chiral catalyst activity, enantioselectivity, and stability are investigated in detail.

\section{Experimental}

\subsection{General}

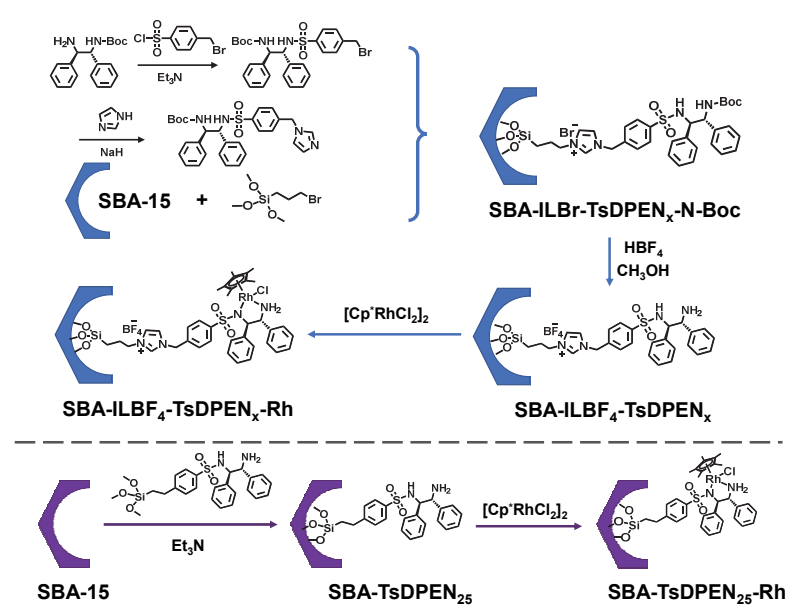

Scheme 1. SBA-ILBF 4 -TsDPEN ${ }_{x}$-Rh synthesis and chiral ligand immobilization on SBA-15 via alkane linkage (SBA-TsDPEN $25-\mathrm{Rh}$ ).
All reagents were purchased from commercial sources and used without further purification. $\left[\mathrm{Cp}^{*} \mathrm{RhCl}_{2}\right]_{2}\left(\mathrm{Cp}^{*}=\right.$ pentamethylcyclopentadiene), di-tert-butyl dicarbonate, and 4-bromomethylphenylsulfonyl chloride were purchased from Bide Pharmaceutical Technology Co., Ltd. $(1 R, 2 R)$-diphenylethylenediamine was purchased from Leyan Pharmaceutical Technology Co., Ltd. Fluoroboric acid solution was purchased from Shanghai Chemical Reagent Company. Sodium hydride was purchased from Aladdin Industrial Corporation. 4-(2-(trimethoxysilyl)ethyl)benzenesulfonyl chloride was purchased from Acros Organics. tert-Butyl [(1R,2R)-2-amino-1,2diphenylethyl]carbamate [22], $(1 R, 2 R)-N$-Boc- $N$ '-(4-bromomethylphenylsulfonyl)-1,2-diphenylethylenediamine [23], $\mathrm{N}$-(2-amino-1,2-diphenylethyl)-4-(2-(trimethoxysilyl)ethyl)ben zenesulfonamide [24] and SBA-15 [25] were synthesized based on the literature method.

Liquid ${ }^{1} \mathrm{H}$ and ${ }^{13} \mathrm{C}$ NMR spectra were measured using a Bruker Avance $400 \mathrm{MHz}$ spectrometer. The solid-state ${ }^{13} \mathrm{C}$ $\mathrm{CP} / \mathrm{TOSS}$ (total suppression of spinning sidebands) spectrum was measured using a Bruker $600 \mathrm{MHz}$ spectrometer. The nitrogen adsorption measurements were performed using a Micromeritics ASAP 2020 physisorption analyzer after the samples were degassed at $120^{\circ} \mathrm{C}$ for $5 \mathrm{~h}$. The pore diameter was defined from $\mathrm{BJH}$ adsorption and the pore volume was calculated, with pore diameters between 1.7-300.0 nm. Thermogravimetric analyses (TGA) were carried out using a NETZSCH STA-449F3 analyzer, under air atmosphere from $30-1000{ }^{\circ} \mathrm{C}$, with a $10{ }^{\circ} \mathrm{C} / \mathrm{min}$ heating rate. The $\mathrm{C} / \mathrm{S}$ contents were quantified using a HORIBA EMIA-930 carbon/sulfur analyzer. Transmission electron microscopy images were obtained using a HITACHI HT7700. The Fourier transform infrared spectra were measured using a Nicolet IS50 IR spectrometer in the range 400-4000 $\mathrm{cm}^{-1}$. The Rh-complex concentration within the filtrates was determined using a SHIMADZU UV-Vis 2550 spectrophotometer. The leached Rh contents were measured with inductively coupled plasma atomic emission spectrometry (ICP-AES) using a SHIMADZU ICPS-8100. X-ray powder diffraction (PXRD) patterns were measured using a Rigaku D/Max-2500 powder diffraction system, equipped with $\mathrm{Cu} K_{\alpha}$ radiation $(\lambda=1.54 \AA)$.

\subsection{Synthesis of tert-Butyl [(1R,2R)-2-amino- 1,2-diphenylethyl]carbamate}

tert-Butyl $[(1 R, 2 R)$-2-amino-1,2-diphenylethyl $]$ carbamate was synthesized according to the reported method [22]. Aqueous $\mathrm{HCl}$ solution (14.2 $\mathrm{mL}, 5.2 \mathrm{M}$ ) was added dropwise to a solution of $(1 R, 2 R)$-diphenylethylenediamine $(10.0 \mathrm{~g}, 47.1$ mmol) in $100 \mathrm{~mL}$ of $\mathrm{MeOH}$. Di-tert-butyl decarbonate (11.3 g, $51.8 \mathrm{mmol}$ ) was added after stirring at room temperature for 1 h. The mixture was stirred at room temperature for another 12 $\mathrm{h}$, and then water $(100 \mathrm{~mL})$ was added. After the precipitate was removed by filtration, $\mathrm{MeOH}$ in the filtrate was removed by rotary evaporation. The transparent aqueous solution was basified with $\mathrm{NaOH}$ to form a solid product. After filtration, the solid product was azeotropically dehydrated with $n$-hexane to afford colorless, acicular crystals, which were dried under vac- 
uum (8.88 g, 60\%). ${ }^{1} \mathrm{H}$ NMR spectrum $\left(\mathrm{CDCl}_{3}, 400 \mathrm{MHz}\right) \delta$ 7.34-7.19 (10H, m), $5.74(1 \mathrm{H}, \mathrm{s}), 4.82(1 \mathrm{H}, \mathrm{s}), 4.31(1 \mathrm{H}, \mathrm{s}), 1.29$ $(12 \mathrm{H}, \mathrm{s})$.

\subsection{Synthesis of $(1 R, 2 R)-N-B o c-N$-(4-bromomethylphenyl- sulfonyl)-1,2-diphenylethylenediamine}

$(1 R, 2 R)-N$-Boc- $N$ '-(4-bromomethylphenylsulfonyl)-1,2-diph enylethylenediamine was synthesized according to the reported method [23]. tert-Butyl [(1R,2R)-2-amino-1,2-diphenylethyl]carbamate $(1.87 \mathrm{~g}, 6.0 \mathrm{mmol})$ in $20 \mathrm{~mL}$ of DCM was added to $\mathrm{Et}_{3} \mathrm{~N} \quad(0.84 \mathrm{~mL}, \quad 6.0 \mathrm{mmol})$. 4-bromomethylphenylsulfonyl chloride/DCM solution (1.94 g, $7.2 \mathrm{mmol} / 10 \mathrm{~mL}$ of DCM) was added dropwise at $0{ }^{\circ} \mathrm{C}$. Water was added to the mixture after stirring at room temperature for $2 \mathrm{~h}$. The organic phase was separated and washed with brine. After drying with $\mathrm{Na}_{2} \mathrm{SO}_{4}$, DCM was removed. The solid was purified using column chromatography (silica gel, eluent: DCM) $\left(2.29\right.$ g, 70\%). ${ }^{1} \mathrm{H}$ NMR spectrum $\left(\mathrm{CDCl}_{3}, 400 \mathrm{MHz}\right) \delta 7.45$ (2H, d), 7.21-7.16 (5H, m), 7.00-6.94 (5H, m), $6.75(2 \mathrm{H}, \mathrm{d}), 6.39$ $(1 \mathrm{H}, \mathrm{s}), 5.24(1 \mathrm{H}, \mathrm{s}), 4.80(1 \mathrm{H}, \mathrm{dd}), 4.64(1 \mathrm{H}, \mathrm{dd}), 4.36(2 \mathrm{H}, \mathrm{s})$, $1.78(9 \mathrm{H}, \mathrm{s})$.

\subsection{Synthesis of tert-butyl ((1R,2R)-2-((4-((1H-imidazol-1-yl) methyl)phenyl)sulfonamido)-1,2-diphenylethyl)carbamate (im- idazole-TsDPEN-N-Boc)}

Imidazole (0.5 g, $7.3 \mathrm{mmol})$ and $\mathrm{NaH}(0.32 \mathrm{~g}, 8 \mathrm{mmol})$ were dispersed in $40 \mathrm{~mL}$ of anhydrous THF. The mixture was refluxed at $70^{\circ} \mathrm{C}$ for $1 \mathrm{~h}$ under $\mathrm{N}_{2}$ atmosphere. After cooling to room temperature, a THF solution containing $(1 R, 2 R)-N$ Boc- $N$ '-(4-bromomethylphenylsulfonyl)-1,2-diphenylethylened iamine $(2.0 \mathrm{~g}, 2.4 \mathrm{mmol})$ was added. After refluxing at $70{ }^{\circ} \mathrm{C}$ overnight, the reaction was quenched with saturated aqueous $\mathrm{NH}_{4} \mathrm{Cl}$. The THF was then removed under reduced pressure and the product was extracted with DCM. The organic phase was washed with brine and dried over $\mathrm{Na}_{2} \mathrm{SO}_{4}$. The product was collected as a white powder after solvent removal. The yield was estimated to be $80 \%$. ${ }^{1} \mathrm{H}$ NMR spectrum $\left(\mathrm{CDCl}_{3}, 400 \mathrm{MHz}\right)$ $\delta 7.51(1 \mathrm{H}, \mathrm{s}), 7.44(2 \mathrm{H}, \mathrm{d}), 7.16-7.13(4 \mathrm{H}, \mathrm{m}), 6.97-6.86(7 \mathrm{H}$, $\mathrm{m}), 6.81(1 \mathrm{H}, \mathrm{s}), 7.11(2 \mathrm{H}, \mathrm{d}), 5.42(1 \mathrm{H}, \mathrm{s}), 5.03(2 \mathrm{H}, \mathrm{s}), 4.81(1 \mathrm{H}$, t), $4.65(1 \mathrm{H}, \mathrm{t}), 1.45(9 \mathrm{H}, \mathrm{s}) .{ }^{13} \mathrm{C}$ NMR spectrum $\left(\mathrm{CDCl}_{3}, 101\right.$ MHz) $\delta 156.10,141.10,140.02,137.41,137.50,130.02,128.56$, $127.89,127.46,127.42,127.40,127.26,127.09,119.16,80.73$, $62.27,60.06,53.40,28.31$.

\subsection{Synthesis of N-(2-amino-1,2-diphenylethyl)-4- (2-(trimethoxysilyl)ethyl)benzenesulfonamide}

$N$-(2-amino-1,2-diphenylethyl)-4-(2-(trimethoxysilyl)ethyl) benzenesulfonamide was synthesized according to the reported method [24]. (1R,2R)-Diphenylethylenediamine (0.636 g, 3.0 $\mathrm{mmol})$ and $\mathrm{Et}_{3} \mathrm{~N}(0.6 \mathrm{~mL}, 4.3 \mathrm{mmol})$ were dissolved in $30 \mathrm{~mL}$ of dry DCM, followed by dropwise addition, in an ice-water bath, of 4-(2-(trimethoxysilyl)ethyl)benzenesulfonyl chloride (1.5 $\mathrm{mL}, 2.31 \mathrm{mmol}$ ) diluted with $30 \mathrm{~mL}$ dry DCM. The mixture was then stirred at room temperature for $3 \mathrm{~h}$. After concentration, the solid was purified using column chromatography (silica gel, eluent: DCM:MeOH:Et $3 \mathrm{~N}=100: 10: 1) .{ }^{1} \mathrm{H}$ NMR spectrum $\left(\mathrm{CDCl}_{3}\right.$, $400 \mathrm{MHz}) \delta 7.33(2 \mathrm{H}, \mathrm{d}), 7.21-7.06(10 \mathrm{H}, \mathrm{m}), 7.01(2 \mathrm{H}, \mathrm{d}), 6.01$ $(1 \mathrm{H}, \mathrm{s}), 4.38(1 \mathrm{H}, \mathrm{d}), 4.12(1 \mathrm{H}, \mathrm{d}), 3.59(9 \mathrm{H}, \mathrm{s}), 2.67(2 \mathrm{H}, \mathrm{m})$, $1.61(2 \mathrm{H}, \mathrm{s}), 0.92(2 \mathrm{H}, \mathrm{m})$.

\subsection{Immobilization of chiral TsDPEN ligands on SBA-15 via IL linkages}

In a typical procedure, desired amounts of 3-(trimethoxysilyl)propyl bromide and imidazole-TsDPEN- $N$-Boc (mole ratio 1.5:1) were added to $2.0 \mathrm{~g}$ of SBA-15 (activated by vacuum degassing at $120^{\circ} \mathrm{C}$ for $3 \mathrm{~h}$ ) dispersed in $40 \mathrm{~mL}$ of anhydrous toluene. The mixture was then refluxed at $110{ }^{\circ} \mathrm{C}$ for $48 \mathrm{~h}$ under $\mathrm{N}_{2}$ atmosphere. After filtration and washing with dichloromethane, a solid was obtained after drying under vacuum, denoted as SBA-ILBrTsDPEN $_{x}-N$-Boc (Br refers to the anions of imidazolium, $x$ refers to the mass ratio of organic compounds in the initial mixture). To remove the Boc protecting group, $0.5 \mathrm{~g}$ of SBA-ILBrTsDPEN $_{x}-N$-Boc was dispersed in methanol $(6 \mathrm{~mL})$, followed by the addition of aqueous $\mathrm{HBF}_{4}(6 \mathrm{~mL}, 40 \mathrm{wt} \%)$. After stirring at room temperature for $12 \mathrm{~h}$, the solid obtained by filtration was dispersed in saturated aqueous $\mathrm{NaHCO}_{3}(20 \mathrm{~mL})$ for $12 \mathrm{~h}$. The solid product isolated by filtration was washed with deionized water and ethanol and dried under vacuum. The sample was denoted as SBA-ILBF 4 -TsDPEN ${ }_{x}$, where $\mathrm{BF}_{4}$ refers to the anions of the IL tethers.

\subsection{Immobilization of chiral TSDPEN ligands on SBA-15 via alkane linkages}

The immobilization of chiral TsDPEN ligands on SBA-15 via alkane linkages was achieved according to the reported method. $0.9 \mathrm{~g}$ of $(1 R, 2 R)$-4-((trimethoxysilyl)ethyl)phenylsulfonyl1,2-diphenylethylenediamine, $2.4 \mathrm{~mL}$ of anhydrous $\mathrm{Et}_{3} \mathrm{~N}$ and $2.0 \mathrm{~g}$ of SBA- 15 (activated by vacuum degassing at $120^{\circ} \mathrm{C}$ for 3 h) were dispersed in $40 \mathrm{~mL}$ of anhydrous toluene. The mixture was refluxed at $110{ }^{\circ} \mathrm{C}$ overnight under $\mathrm{N}_{2}$ atmosphere. The solid was washed thoroughly with methanol and dried under vacuum. The sample was denoted as SBA-TsDPEN 25 , where 25 represents the mass ratio of chiral ligands in the initial mixture.

\subsection{Preparation of solid catalysts by SBA-ILBF 4 -TSDPEN $N_{x}$ or SBA-TsDPEN 25 coordination with $\left[\mathrm{Cp}^{*} \mathrm{RhCl}_{2}\right]_{2}$}

In a typical procedure, $300 \mathrm{mg}$ of SBA-ILBF $4-\mathrm{TsDPEN}_{x}$ or SBA-TsDPEN $_{25}$ was dispersed in $7 \mathrm{~mL}$ of dichloromethane (DCM), followed by the addition of $\left[\mathrm{Cp}^{*} \mathrm{RhCl}_{2}\right]_{2}$ (2.1 eq. to the amounts of immobilized TsDPEN) at room temperature. The resulting mixture was stirred at room temperature for $12 \mathrm{~h}$. After filtration, the residue was washed with $\mathrm{MeOH}$ and dried under reduced pressure. Solid catalyst SBA-ILBF 4 -TsDPEN ${ }_{x}-\mathrm{Rh}$ or SBA-TsDPEN $25-\mathrm{Rh}$ was then obtained. The solvent in the filtrate was vaporized and the uncoordinated metal salts were dissolved in DCM. The amounts of Rh in DCM were measured using UV-Vis spectrophotometry. The Rh content in the solid 
catalysts was calculated by $\left(m_{0}-m_{1}\right) / \mathrm{W}$, where $\mathrm{m}_{0}$ and $\mathrm{m}_{1}$ respectively refer to the $\mathrm{Rh}$ mass in the initial mixture and in DCM, and $W$ refers to the weight of SBA-ILBF $4-$ TsDPEN $_{x}$-Rh or SBA-TsDPEN $25-R h$.

\subsection{Preparation of homogeneous $C p^{*} R h-T s D P E N$ catalyst}

$\left[\mathrm{Cp}^{*} \mathrm{RhCl}_{2}\right]_{2}$ (253 mg) and $\mathrm{N}-((1 R, 2 R)-2$-amino-1,2-diphenylethyl)-4-methylbenzenesulfonamide (300 mg) were dispersed in DCM $(10 \mathrm{~mL})$. The solvent was removed to obtain homogeneous catalyst $\mathrm{Cp} * \mathrm{Rh}-\mathrm{TsDPEN}$ after stirring at room temperature for $30 \mathrm{~min}$.

\section{Results and discussion}

\subsection{Synthesis and characterization}

As illustrated in Scheme 1, the chiral ligand TsDPEN was immobilized in the SBA-15 mesopores via a simple one-pot grafting method. Unlike previous reports, the TsDPEN was immobilized on SBA-15 via an ionic liquid linker (imidazolium ion). In the first step, mono-Boc-protected $(1 R, 2 R)-1,2$-diphenylethylene-1,2-diamine was synthesized, followed by the reaction with 4-bromomethylphenylsulfonyl chloride. The benzyl bromide group was further reacted with imidazole and $\mathrm{NaH}$ to obtain imidazole-TsDPEN- $N$-Boc. The grafting of 3-(trimethoxysilyl)propyl bromide onto SBA-15 and the reaction of imidazole-TsDPEN- $N$-Boc with 3-(trimethoxysilyl)propyl bromide took place simultaneously. This one-step grafting and reaction reduced the tedious synthesis steps. The following deprotection, ion-exchange, and $\mathrm{Rh}$ coordination resulted in the formation of the chiral solid catalysts SBA-ILBF $_{4}-\mathrm{TsDPEN}_{x}$-Rh. A control sample, SBA-TsDPEN $25-\mathrm{Rh}$, was also prepared by grafting $(1 R, 2 R)-4-(($ trimethoxysilyl)ethyl)phenylsulfonyl-1,2-diphenylethylenediamine into the SBA-15 mesopores according to a previously reported method (Scheme 1) [24].

The chemical compositions of imidazole-TsDEPN- $N$-Boc and SBA-ILBF $_{4}$-TsDPEN ${ }_{x}$ were analyzed using FT-IR and NMR spectroscopy. In the FT-IR spectrum of imidazole-TsDPEN- $N$-Boc, $\mathrm{S}=0$ stretching vibrations at 1160 and $1340 \mathrm{~cm}^{-1}$ were observed, as well as the 4 vibrations of the phenyl rings in the range $1450-1550 \mathrm{~cm}^{-1}$. A peak at $1587 \mathrm{~cm}^{-1}$ could be attributed to the in-plane $\mathrm{A}_{1}$ mode of the $\mathrm{CH}_{2}$ group connected to the imidazole nitrogen atom [26], confirming the connection between the chiral ligand and imidazole. The strong vibration at $1710 \mathrm{~cm}^{-1}$ was assigned to the characteristic stretching of the Boc $\mathrm{C}=0$ group (Fig. 1(a)). The ${ }^{13} \mathrm{C}$ NMR spectrum of imidazole-TsDPEN- $N$-Boc clearly revealed characteristic carbon signals for the phenyl rings and imidazolium ring between 119 and $141 \mathrm{ppm}$. The carbon signals representing the 2 chiral carbon atoms within the chiral ligand are situated at 60 and 64 ppm, respectively. Furthermore, the signals representing the carbon atoms of the Boc group are also clearly observed at 28, 81, and 157 ppm (Fig. 1(c)). FT-IR analysis was also carried out to characterize SBA-ILBF 4 -TsDPEN ${ }_{x}$ (Fig. 1(b) and Fig. S1). Using SBA-ILBF 4 -TsDPEN50 as a representative sample, the characteristic peaks for $\mathrm{C}=\mathrm{C}$ vibrations of the phenyl ring at $\sim 1450-1550 \mathrm{~cm}^{-1}$ and the $\mathrm{S}=0$ stretching peak at $1157 \mathrm{~cm}^{-1}$ originating from the chiral ligands are clearly observed
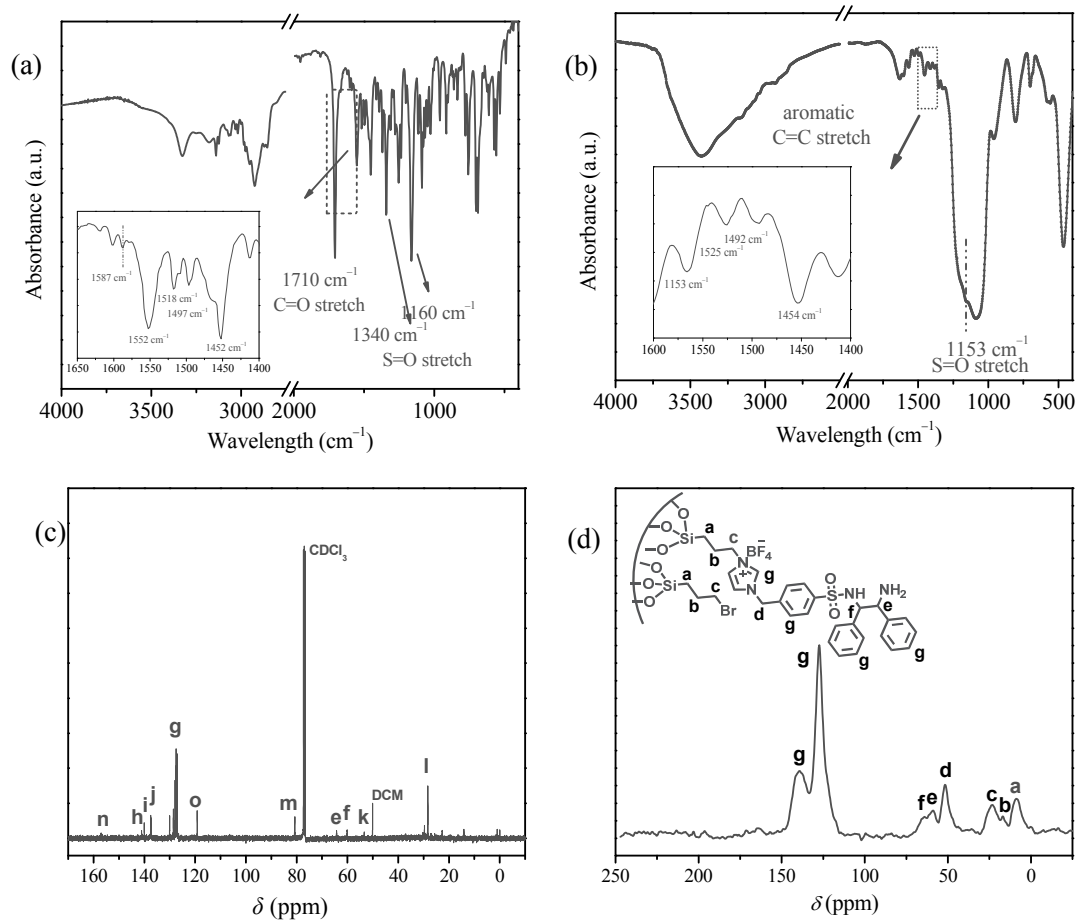

Fig. 1. FT-IR spectra of imidazole-TsDPEN- $N$-Boc (a) and SBA-ILBF 4 -TsDPEN 50 (b); (c) ${ }^{13} \mathrm{C}$ NMR spectrum of imidazole-TsDPEN- $N$-Boc in $C D C l$; $\left(\right.$ d) ${ }^{13} \mathrm{C}$ $\mathrm{CP} / \mathrm{TOSS}$ NMR spectrum of SBA-ILBF $4-\mathrm{TsDPEN}_{50}$. 
Table 1

Physicochemical parameters of SBA-15, SBA-ILBF - TsDPEN $_{x}$ and SBA-TsDPEN 25 before and after coordination with the Rh complex a

\begin{tabular}{|c|c|c|c|c|c|c|c|c|}
\hline Sample & $\begin{array}{c}S_{\mathrm{BET}} \\
\left(\mathrm{m}^{2} / \mathrm{g}\right)\end{array}$ & $\begin{array}{c}D_{\mathrm{p}} \\
(\mathrm{nm})\end{array}$ & $\begin{array}{c}V_{\mathrm{p}} \\
\left(\mathrm{cm}^{3} / \mathrm{g}\right)\end{array}$ & $\begin{array}{l}\text { S content }{ }^{\mathrm{b}} \\
(\mathrm{mmol} / \mathrm{g})\end{array}$ & $\begin{array}{l}\text { C content } \mathrm{b} \\
(\mathrm{mmol} / \mathrm{g})\end{array}$ & $\begin{array}{l}\text { Rh content }^{\mathrm{c}} \\
(\mathrm{mmol} / \mathrm{g})\end{array}$ & $\begin{array}{c}\text { Weight loss }{ }^{\mathrm{d}} \\
(\mathrm{wt} \%)\end{array}$ & $\begin{array}{c}\left(\mathrm{CH}_{2}\right)_{3} \mathrm{Br} \mathrm{e}^{\mathrm{e}} \\
(\mathrm{wt} \%)\end{array}$ \\
\hline SBA-15 & 713 & 7.5 & 0.82 & - & - & - & - & - \\
\hline $\mathrm{SBA} \mathrm{ILBF}_{4}-\mathrm{TsDPEN}_{20}$ & 407 (372) & $6.4(6.4)$ & $0.64(0.54)$ & 0.16 & 6.9 & $(0.09)$ & 17.4 & 8.4 \\
\hline SBA-ILBF $_{4}-\mathrm{TsDPEN}_{35}$ & $315(250)$ & $6.3(5.4)$ & $0.46(0.37)$ & 0.35 & 12.2 & $(0.21)$ & 24.7 & 5.7 \\
\hline SBA-ILBF $_{4}-\mathrm{TsDPEN}_{50}$ & $311(252)$ & $5.4(5.4)$ & $0.46(0.38)$ & 0.39 & 12.7 & $(0.23)$ & 27.3 & 5.9 \\
\hline SBA-TsDPEN $_{25}$ & $341(256)$ & $5.4(5.5)$ & $0.47(0.36)$ & 0.65 & 14.4 & $(0.20)$ & 25.1 & - \\
\hline
\end{tabular}

${ }^{a}$ Data in brackets refer to the Rh-coordinated sample. ${ }^{b}$ Measured using C/S elemental analysis. ${ }^{c}$ Calculated with the filtrate Rh concentration meas-

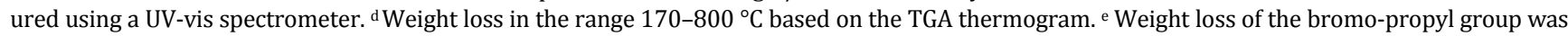
calculated by $W_{\mathrm{TGA}}-W_{\mathrm{S}}$, where $\mathrm{W}_{\mathrm{TGA}}$ is the weight-loss from TGA thermograms and $W_{\mathrm{S}}$ is the weight-loss of the chiral ligands, calculated based on $\mathrm{S}$ content.

[27-29], demonstrating the successful incorporation of the chiral ligands with IL linkages into SBA-15 by this one-pot method. In comparison with imidazole-TsDPEN- $N$-Boc, the characteristic peak of the $\mathrm{C}=0$ stretching vibration at $1710 \mathrm{~cm}^{-1}$ shifted slightly to $1700 \mathrm{~cm}^{-1}$ for SBA-ILBr-TsDPEN ${ }^{-}-N$-Boc (Fig. S1(a)), which is attributed to the interaction between silica and the organic compound. The absence of the $1700 \mathrm{~cm}^{-1}$ vibration in the SBA-ILBF 4 -TsDPEN50 spectrum confirmed the complete removal of the Boc group (Fig. S1(b)). The representative ${ }^{13} \mathrm{C}$ CP/TOSS NMR spectrum of SBA-ILBF 4 -TsDPEN 50 (Fig. 1(d)) clearly shows peaks at (e) 59 and (f) 64 ppm assigned to the chiral carbon atoms of the chiral ligands, and the peaks at $(\mathrm{g})$ 139 and 127 ppm corresponding to the carbon atoms in the benzene ring and cationic imidazolium ring, respectively. The signal at (d) $52 \mathrm{ppm}$ was assigned to the $-\mathrm{CH}_{2}$ - carbon in the benzyl group. Signals at (a) 9, (b) 16, and (c) 23 ppm are assigned to the $\mathrm{C}_{1}, \mathrm{C}_{2}$, and $\mathrm{C}_{3}$ carbons of $\mathrm{Si}-\mathrm{C}^{1} \mathrm{H}_{2} \mathrm{C}^{2} \mathrm{H}_{2} \mathrm{C}^{3} \mathrm{H}_{2}$. The FT-IR and ${ }^{13} \mathrm{C} \mathrm{CP} / \mathrm{TOSS}$ NMR spectra showed the successful grafting of the chiral ligand onto SBA-15.
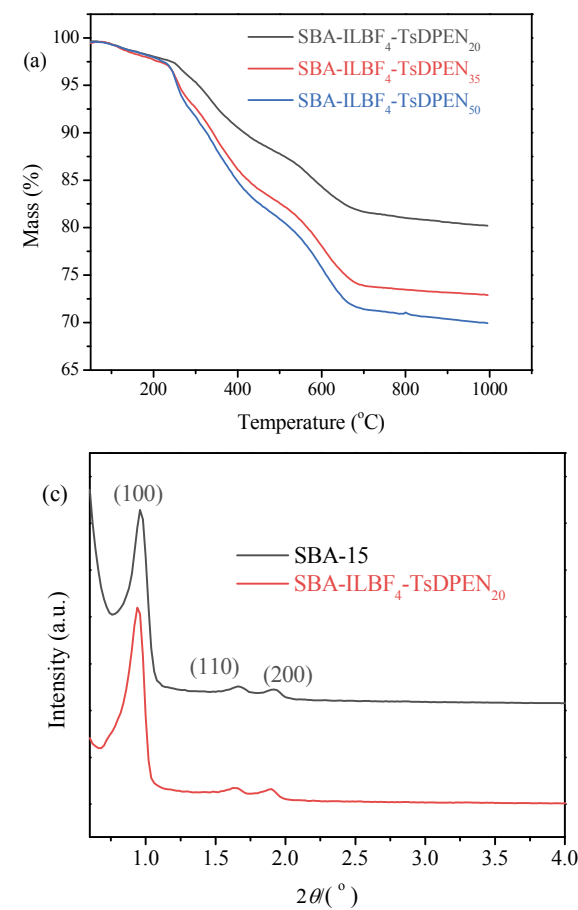

Sulfur detection by elemental analysis confirmed the successful immobilization of TsDPEN on SBA-15 (Table 1). The chiral ligand content is equal to the $S$ content in

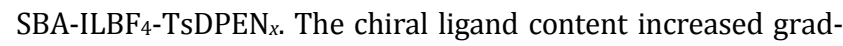
ually from 0.17 to $0.39 \mathrm{mmol} / \mathrm{g}$ with increasing imidazole-TsDPEN- $N$-Boc content in the initial mixture. However, only a slight increase in the chiral ligand content was observed by increasing imidazole-TsDPEN- $N$-Boc content from 35-50 wt\% in the initial mixture, suggesting the maximum immobilization content of chiral ligand was ca. $0.39 \mathrm{mmol} / \mathrm{g}$. The $\mathrm{C} / \mathrm{S}$ mole ratio of SBA-ILBF 4 -TsDPEN ${ }_{x}$ was more than 30 , higher than the theoretical value of 27 , revealing the existence of unreacted bromo-propyl groups.

The thermal stability of SBA-ILBF 4 -TsDPEN $x$ was measured using TGA (Fig. 2(a)). The first weight loss at low temperature $\left(50-170{ }^{\circ} \mathrm{C}\right)$ was assigned to the loss of physically adsorbed water. Irrespective of the chiral ligand content, the first weight loss for all materials is ca. $1.2 \mathrm{wt} \%$, indicating similar hydrophobicity/hydrophilicity of the materials. The weight loss

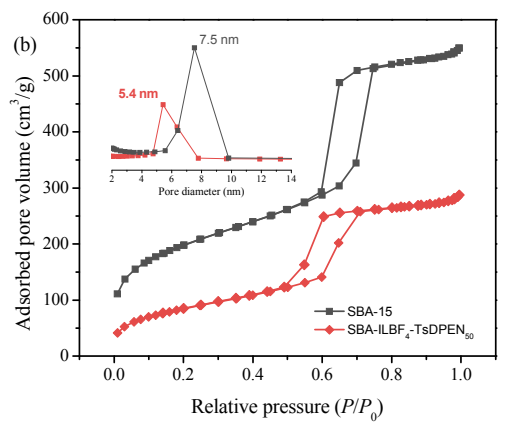

(d)

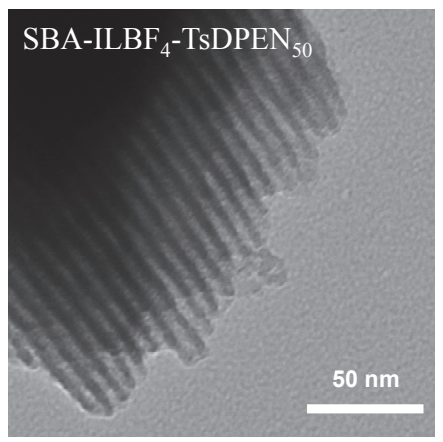

Fig. 2. (a) TGA curves; (b) $\mathrm{N}_{2}$ sorption isotherms (inset is the pore size distribution curves); (c) XRD patterns; (d) TEM image of SBA-ILBF 4 -TsDPEN 50 . 
above $170{ }^{\circ} \mathrm{C}$ was from the decomposition of the organic groups and increased as the initial imidazole-TsDPEN- $N$-Boc content increased, consistent with elemental analysis results [25]. The weight loss assigned to the chiral ligand was calculated based on $\mathrm{S}$ elemental analysis. Thus, the free bromo-propyl group content was obtained by the difference between the TGA weight-loss and the weight loss calculated based on $S$ content (Table 1). It is interesting to observe that the free bromo-propyl group contents of SBA-ILBF 4 -TsDPEN 35 and SBA-ILBF $_{4}-\mathrm{TsDPEN}_{50}$ were much less than that of $\mathrm{SBA}_{\mathrm{ILBF}}-\mathrm{TsDPEN}_{20}$, though the mole ratio of imidazole-TsDPEN- $N$-Boc and 3-(trimethoxysilyl)propyl bromide $(1.5 / 1)$ was the same in the initial synthesis mixture for all samples. During the one-pot grafting process, at least 2 reactions take place: the grafting of the silane precursor onto SBA-15 and the reaction of the propyl bromide group with imidazole-TsDPEN- $N$-Boc. If the bromo-propyl group and imidazole-TsDPEN- $N$-Boc reaction rate is fast enough to compete with the grafting rate of 3-(trimethoxysilyl)propyl bromide onto SBA-15, the SBA-15 mesopores could be occupied by the large chiral ligands, which may impede further grafting of the 3-(trimethoxysilyl)propyl bromide. This tendency is strengthened with higher organic precursor content in the initial mixture. The less free bromo-propyl groups within SBA-ILBF $_{4}-\mathrm{TsDPEN}_{35}$ and SBA-ILBF 4 -TsDPEN 50 indicate the fast reaction rate of the bromo-propyl group and imidazole-TsDPEN- $N$-Boc during the one-pot grafting process.

After Rh-precursor coordination, SBA-ILBF 4 -TsDPEN $\mathrm{S}_{x}$-Rh catalysts were formed. The $\mathrm{Rh}$ content of $\mathrm{SBA}_{-} \mathrm{ILBF}_{4}$ TsDPEN $_{x}$-Rh varied in the range 0.09-0.23 mmol/g, determined by ICP. For SBA-ILBF $-\mathrm{TsDPEN}_{35}$ and SBA-ILBF $4-\mathrm{TsDPEN}_{50}$, ca. $62 \%$ of the chiral ligands could be coordinated to Rh, decreasing to ca. $52 \%$ for SBA-ILBF $4-\mathrm{TsDPEN}_{20}$, possibly due to its high free bromo-propyl group content. The control sample SBA-TsDPEN $_{25}$ had S and Rh contents of 0.65 and $0.20 \mathrm{mmol} / \mathrm{g}$, respectively, suggesting that only $33 \%$ of the chiral ligands could coordinate to $\mathrm{Rh}$.

The textural properties of SBA-ILBF 4 -TsDPEN $x$ were characterized using $\mathrm{N}_{2}$ sorption (Tables 1 and S1, Figs. 2(b) and S3). SBA-ILBF $_{4}-\mathrm{TsDPEN}_{x}$ displayed type-IV sorption isotherms with a sharp hysteresis loop at $P / P_{0}$ of $0.4-0.8$, characteristic of mesoporous materials with an ordered, hexagonal mesostructure [30]. In comparison with parent SBA-15, the hysteresis loop shifted to lower $P / P_{0}$ values, revealing the pore size decrease. This is further verified by the smaller pore diameter of SBA-ILBF $_{4}-\mathrm{TsDPEN}_{x}$ than those of parent SBA-15, indicating chiral ligand occupation within the SBA-15 mesopores. The BET surface area and pore volume of SBA-ILBF 4 -TsDPEN Tere $_{x}$ wer much smaller than those of SBA-15. SBA-ILBF - TsDPEN $_{20}$ had a

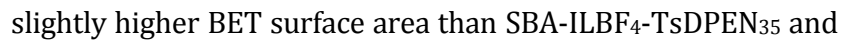
SBA-ILBF $_{4}-\mathrm{TsDPEN}_{50}$. The BET surface area of SBA-ILBF 4 $\operatorname{TsDPEN}_{x}$ was proportional to the immobilized chiral ligand content. The control sample, SBA-TsDPEN 25 , had almost the same pore size and pore volume as $\mathrm{SBA}_{-} \mathrm{ILBF}_{4}-\mathrm{TsDPEN}_{50}$. A decrease in the BET surface area, as well as pore volume, of SBA-ILBF $_{4}-\mathrm{TsDPEN}_{x}$ and SBA-TsDPEN 25 was observed after Rh coordination.

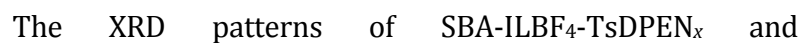
SBA-TsDPEN 25 show a clear (100) diffraction peak, indicating that the ordered mesostructure was maintained after chiral ligand immobilization (Figs. 2(c) and S4) [30]. The (110) and (200) diffraction peaks were well maintained in the SBA-ILBF $_{4}-\mathrm{TsDPEN}_{20}$ XRD pattern. These two peaks are not easily observed for SBA-ILBF 4 -TsDPEN 35 and SBA-ILBF 4 TsDPEN $_{50}$, possibly related to the decrease in contrast due to the pore occupation by the chiral ligands. The representative TEM image of SBA-ILBF 4 -TsDPEN S $_{50}$ clearly shows the ordered mesopores, confirming the mesoporous structure of the hybrid materials (Figs. 2(d) and S5).

\subsection{Quinaldine asymmetric transfer hydrogenation}

The catalytic performance of the SBA-ILBF $4-\mathrm{TsDPEN}_{x}$-Rh catalysts in quinaldine ATH was investigated (Table 2). To exclude the external diffusion influence on the catalytic performance, the SBA-ILBF 4 -TsDPEN ${ }_{x}$-Rh activity was tested at different stirring rates (Tables 2 and S3). With stirring rates of 500 or $1000 \mathrm{rpm}$, SBA-ILBF-TsDPEN50-Rh afforded similar product yields and ee values, suggesting the 500-1000 rpm stirring rate is fast enough to avoid the external diffusion influence on the reaction. Thus, in the following study, the stirring rate was set at $1000 \mathrm{rpm}$. All SBA-ILBF $4-\mathrm{TsDPEN}_{x}$-Rh catalysts could efficiently catalyze quinaldine ATH for the formation of $(R)$-2-methyl-1,2,3,4-tetrahydroquinoline, with $84 \%-86 \%$ conversion and $91 \%$ ee (Table 2, entries 2-4). SBA-ILBF 4 TsDPEN $_{20}-\mathrm{Rh}$, with the lowest chiral active site content showed the highest turnover frequency (TOF, $92 \mathrm{~h}^{-1}$ ) (Table 2, entry 2), even higher than that of the homogeneous catalyst $\left(75 \mathrm{~h}^{-1}\right)$ (Table 2, entry 1). SBA-ILBF 4 -TsDPEN $35-\mathrm{Rh}$ and SBA-ILBF 4 TsDPEN 50 -Rh afforded identical TOFs of $63 \mathrm{~h}^{-1}$ (Table 2, entries 3 and 4), slightly lower than the homogeneous catalyst. The

Table 2

Quinaldine asymmetric transfer hydrogenation over homogeneous or heterogeneous catalysts ${ }^{\text {a }}$.

\begin{tabular}{|c|c|c|c|c|c|}
\hline Entry & Catalyst & \multicolumn{4}{|c|}{$T$ (h) Conv. (\%) ee (\%) TOF $\left(\mathrm{h}^{-1}\right)^{\mathrm{b}}$} \\
\hline 1 & $\mathrm{Cp}^{*} \mathrm{Rh}-\mathrm{TsDPEN}$ & 12 & 95 & 95 & 75 \\
\hline 2 & SBA-ILBF $_{4}-\mathrm{TsDPEN}_{20}-\mathrm{Rh}$ & 12 & 86 & 91 & 92 \\
\hline 3 & SBA-ILBF $_{4}-\mathrm{TsDPEN}_{35}-\mathrm{Rh}$ & 12 & 86 & 91 & 63 \\
\hline 4 & 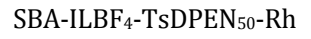 & 12 & 84 & 91 & 63 \\
\hline 5 & SBA-ILBF $_{4}-\mathrm{TsDPEN}_{50}-\mathrm{Rh}$ & 2 & 62 & 93 & - \\
\hline 6 & 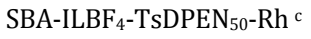 & 2 & 62 & 93 & - \\
\hline 7 & 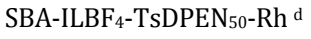 & 1 & 38 & - & - \\
\hline 8 & SBA-ILBF $_{4}-\mathrm{TsDPEN}_{50}-\mathrm{Rh}^{\mathrm{e}}$ & 12 & 93 & 92 & - \\
\hline 9 & 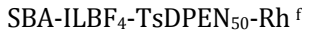 & 12 & 96 & 93 & 93 \\
\hline 10 & SBA-TsDPEN $_{25}-\mathrm{Rh}^{\mathrm{f}}$ & 12 & 90 & 92 & 33 \\
\hline 11 & $\mathrm{SBA}^{-T s D P E N}{ }_{20}-\mathrm{ILBF}_{4}-\mathrm{Rh}^{\mathrm{f}}$ & 12 & 90 & 93 & 60 \\
\hline
\end{tabular}

a Reaction conditions: catalyst (5 $\mu \mathrm{mol} \mathrm{Rh})$, quinaldine $(0.5 \mathrm{mmol})$, HCOONa $2 \mathrm{H}_{2} \mathrm{O}(520 \mathrm{mg}, 5.0 \mathrm{mmol})$ and $5.0 \mathrm{~mL}$ buffer $(\mathrm{pH}=5.0,2 \mathrm{M}$ HOAc-NaOAc), $40{ }^{\circ} \mathrm{C}, 1000 \mathrm{rpm}$. Conversion and ee values were obtained using GC and HPLC, respectively. $\mathrm{b}$ Turnover frequency (TOF) was calculated using the quinaldine conversion at $20 \mathrm{~min}$. ${ }^{\mathrm{c}}$ The recycle experiment was carried out with catalyst used for $2 \mathrm{~h}$, with $80 \mu \mathrm{L}$ $\mathrm{HCOOH}$ added to regenerate the buffer solution and hydrogen source. ${ }^{\mathrm{d}}$ quinaldine $(0.2 \mathrm{mmol})$, racemized 1,2,3,4-tetrahydroquinaldine $(0.3$ mmol), 1 h. e $80 \mu \mathrm{L} \mathrm{HCOOH}$ was added after $6 \mathrm{~h}$, and the mixture was allowed to react for another 6 h. ${ }^{\text {f } 5.0 ~ m L ~} 4$ M HOAc-NaOAc buffered solution with initial $\mathrm{pH}=5.0$ was used as reaction media. 
higher activity of SBA-ILBF 4 -TsDPEN 20 -Rh may be ascribed to its higher BET surface area and larger pore diameter. The ee values of the solid catalysts are slightly lower than their homogeneous counterpart ( $91 \%$ vs. 95\%).

The reaction profiles showed that the initial reaction rate for the homogeneous and solid catalysts is very fast, but the kinetic curves became sluggish with longer reaction times for all catalysts (Fig. 3(a)). For the homogeneous catalyst, $3 \mathrm{~h}$ was required to achieve $80 \%$ conversion and another $9 \mathrm{~h}$ was

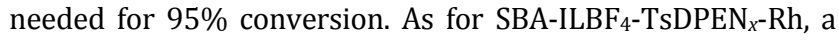
clear reaction rate decrease occurred after $2 \mathrm{~h}$, and $12 \mathrm{~h}$ were required for the conversion increase from $\sim 50 \%$ to $>80 \%$. No noticeable change in the ee value was observed during the reaction for all catalysts.

It is puzzling to observe the more sluggish reaction rate of the solid catalysts in comparison with the homogeneous counterpart at longer reaction times. Initially, we suspected solid catalyst deactivation caused reaction rate retardation, as even after prolonging the reaction time to $18 \mathrm{~h}$, only a few more substrates were transformed. To verify this assumption, a representative recycling experiment with $\mathrm{SBA}_{-} \mathrm{ILBF}_{4}-\mathrm{TsDPEN}_{50}-\mathrm{Rh}$ was performed. After $2 \mathrm{~h}$, the organic phase was extracted with $\mathrm{Et}_{2} \mathrm{O}$ and fresh aliquots of substrate and $80 \mu \mathrm{L}$ of $\mathrm{HCOOH}$ were added. After 2 h, 62\% conversion with 93\% ee was observed, identical to the fresh catalyst (Table 2, entries 5 and 6). This suggested that the solid catalyst was not deactivated during the reaction.

Having excluded the possibility of catalyst deactivation, the sluggish reaction rates observed at longer reaction times are more likely correlated to reaction parameters, such as the substrate concentration and toxic effects of substrates/products on the catalysts. Thus, varied catalyst loading was used for quinaldine ATH with SBA-ILBF4-TsDPEN50-Rh as the model catalyst (Fig. 3(b)). The reaction rate increased almost linearly with decreasing catalyst loading. The reaction rate with catalyst loading of $0.2 \mathrm{~mol} \%$ was almost triple that with catalyst loading of $1 \mathrm{~mol} \%$, and the ee value decreased slightly from $91 \%$ to $90 \%$ when catalyst loading varied from $1 \mathrm{~mol} \%$ to $0.2 \mathrm{~mol} \%$, suggesting no poison effect of substrates on catalysts. The

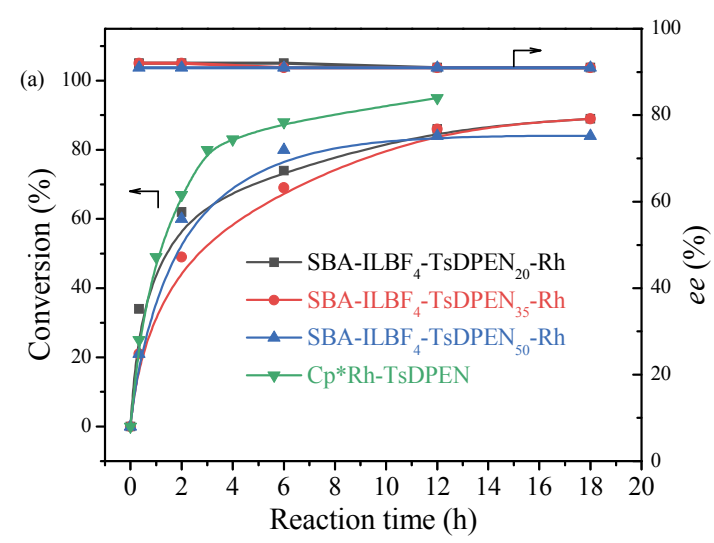

higher reaction rate with low catalyst loading is possibly due to the increased diffusion rate during catalysis. The influence of the product on $\mathrm{SBA}_{-} \mathrm{ILBF}_{4}-\mathrm{TsDPEN}_{50}-\mathrm{Rh}$ was investigated by replacing $0.3 \mathrm{mmol}$ quinaldine with equivalent racemized 1,2,3,4-tetrahydroquinaldine as starting reactants, corresponding to $60 \%$ conversion for the quinaldine reaction system. After $1 \mathrm{~h}, 38 \%$ conversion is achieved (Table 2, entry 7), showing no poison effect by the product.

According to the Xiao's report, the $\mathrm{pH}$ of quinoline ATH controls both reductant (formate) and reactant (protonated quinaldine) concentration, further influencing the reaction process [10]. Thus, the $\mathrm{pH}$ of the aqueous solution at different reaction times was measured with $\mathrm{SBA}_{-} \mathrm{ILBF}_{4}-\mathrm{TsDPEN}_{50}$ - $\mathrm{Rh}$ as the model catalyst (Fig. 4(a)). In $2 \mathrm{~h}$, the reaction system pH increased sharply from 5.13 to 5.57 , accompanied by quinaldine conversion from 0 to $60 \%$. The fast $\mathrm{pH}$ increase is due to HCOONa consumption. At $18 \mathrm{~h}$, the $\mathrm{pH}$ is 5.95 , much higher than the reported $\mathrm{pKa}$ value of protonated quinaldine (5.40). Thus, the deterioration of the reaction rate with increasing reaction time is possibly due to the increase in $\mathrm{pH}$ value.

Adding $\mathrm{HCOOH}$ to the reaction system is a solution to counteract the effect of the $\mathrm{pH}$ fluctuation. With

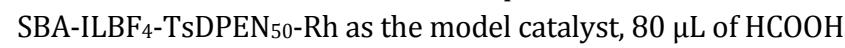
was injected after 6 h. After another 6 h, 93\% conversion was obtained (Table 2, entry 8), higher than that without $\mathrm{HCOOH}$ addition. This showed that the injection of $\mathrm{HCOOH}$ during the reaction provided protons, which could recover the $\mathrm{pH}$ of the mixture to facilitate fast substrate conversion. To prevent a significant rise in $\mathrm{pH}$ value during the catalytic process, HOAc-NaOAc buffer with a higher concentration ( $4 \mathrm{M}, \mathrm{pH}=5.0$ ) was applied for quinaldine ATH. SBA-ILBF 4 -TsDPEN 50 -Rh with 4 M HOAc-NaOAc buffer afforded much higher conversion (96\% vs. 4\%) and ee (93\% vs. 91\%) (Table 2, entry 9) than those obtained with $2 \mathrm{M}$ HOAc-NaOAc buffer. The pH of the reaction system with $4 \mathrm{M}$ HOAc-NaOAc buffer was measured. It was found that higher buffer concentration could not suppress the sharp $\mathrm{pH}$ increase at the initial stage, though the $\mathrm{pH}$ rise was not as severe compared with that of the system with lower buffer concentration (Fig. 4(a)). At the end of the reaction, the

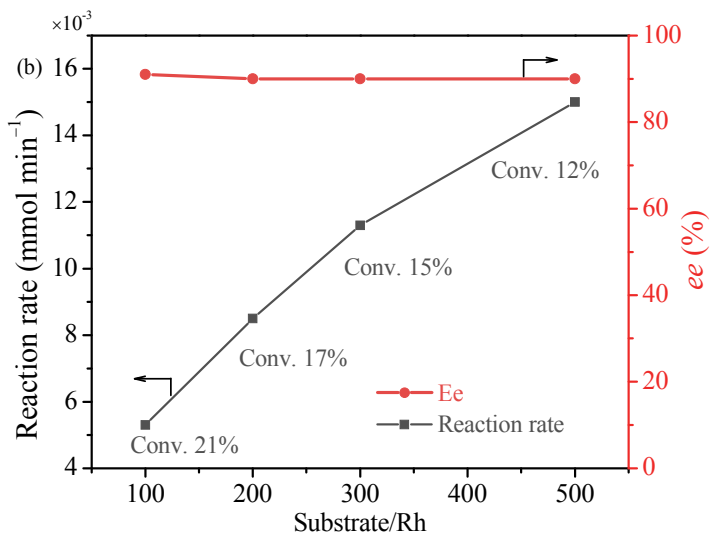

Fig. 3. (a) Reaction profiles as a function of reaction time of SBA-ILBF $-\mathrm{TsDPEN}_{x}$-Rh and TsDPEN-Rh in quinaldine ATH $(5 \mu \mathrm{mol}$ Rh, $0.5 \mathrm{mmol}$ quinaldine, $5 \mathrm{mmol} \mathrm{HCOONa} \cdot 2 \mathrm{H}_{2} \mathrm{O}$ and $5.0 \mathrm{~mL}$ of $2 \mathrm{M} \mathrm{HOAc}-\mathrm{NaOAc}$ buffer with an initial $\mathrm{pH}$ of $5,40^{\circ} \mathrm{C}$ ). (b) Reaction rate and enantioselectivity of quinaldine ATH with different $\mathrm{S} / \mathrm{C}$ ratios over SBA-ILBF 4 -TsDPEN ${ }_{50}-\mathrm{Rh}\left(5 \mathrm{mmol} \mathrm{HCOONa} \cdot 2 \mathrm{H}_{2} \mathrm{O}, 5.0 \mathrm{~mL}\right.$ of $2 \mathrm{M} \mathrm{HOAc-NaOAc} \mathrm{buffer} \mathrm{with} \mathrm{an} \mathrm{initial} \mathrm{pH} \mathrm{of} 5$, $\left.40^{\circ} \mathrm{C}, 20 \mathrm{~min}\right)$. 

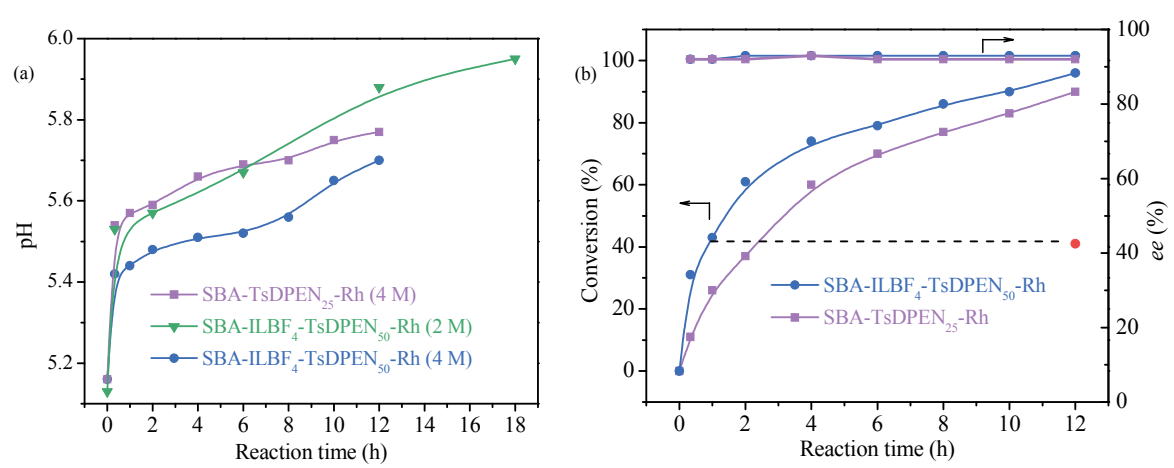

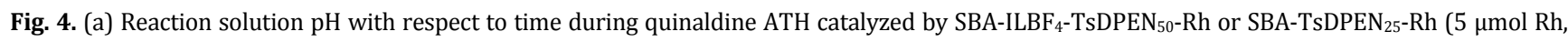
$0.5 \mathrm{mmol}$ quinaldine, $5 \mathrm{mmol} \mathrm{HCOONa} \cdot 2 \mathrm{H}_{2} \mathrm{O}$, and $5.0 \mathrm{~mL}$ of $2 \mathrm{M} / 4 \mathrm{M}$ buffer with $\mathrm{pH}=5,40{ }^{\circ} \mathrm{C}$ ). (b) Reaction profiles as a function of time for $\mathrm{SBA}_{-\mathrm{ILBF}_{4}-\mathrm{TsDPEN}_{50}-\mathrm{Rh} \text { and SBA-TsDPEN }} \mathrm{S}_{2}-\mathrm{Rh}$ in quinaldine ATH $\left(5 \mu \mathrm{mol} \mathrm{Rh}, 0.5 \mathrm{mmol}\right.$ quinaldine, $5 \mathrm{mmol} \mathrm{HCOONa} \cdot 2 \mathrm{H}_{2} \mathrm{O}$, and $5.0 \mathrm{~mL}$ of $4 \mathrm{M}$ HOAc-NaOAc buffer with an initial $\mathrm{pH}$ of $\left.5,40{ }^{\circ} \mathrm{C}\right)$ and hot filtration test for the ATH reaction with SBA-ILBF $-\mathrm{TsDPEN}_{50}-\mathrm{Rh}(\mathrm{red}$ dot $=$ after filtering $\left.\mathrm{SBA}_{-} \mathrm{ILBF}_{4}-\mathrm{TsDPEN}_{50}-\mathrm{Rh}\right)$.

$\mathrm{pH}$ had increased to 5.70 with a final conversion of $96 \%$, much lower compared to that of the $2 \mathrm{M}$ buffer solution after the reaction ( $\mathrm{pH}$ value of 5.95 with conversion of $84 \%$ ).

To clarify the role of the IL linkage, the catalytic performance of SBA-TsDPEN 25 -Rh was tested and compared with SBA-ILBF $_{4}-\mathrm{TsDPEN}_{50}-\mathrm{Rh}$, considering that the 2 samples had similar Rh content and textural properties (Table 1). In $4 \mathrm{M}$ buffer, SBA-TsDPEN 25 -Rh afforded $90 \%$ conversion with $92 \%$ ee (Table 2, entry 10) and SBA-ILBF 4 -TsDPEN 50 -Rh yielded $96 \%$ conversion with $93 \%$ ee in quinaldine ATH. From the reaction profiles, the SBA-TsDPEN $25-\mathrm{Rh}$ reaction rate was much slower than that of SBA-ILBF 4 -TsDPEN 50 -Rh (Fig. 4(b)). The SBA-ILBF 4 -TsDPEN50-Rh with a TOF of $93 \mathrm{~h}^{-1}$ was more active than SBA-TsDPEN $25-\mathrm{Rh}$ with a TOF of $33 \mathrm{~h}^{-1}$. The pH of the reaction system with SBA-TsDPEN $25-\mathrm{Rh}$ is much higher than that of the system with SBA-ILBF 4 -TsDPEN50-Rh at the same reaction time, suggesting that the hydride from $\mathrm{NaCOOH}$ was not efficiently transferred to the substrate with the former catalyst (Fig. 4(a)). Further evidence was obtained using a solid catalyst with co-immobilized TsDPEN ligands and an IL functional group (SBA-TsDPEN $20-\mathrm{ILBF}_{4}-\mathrm{Rh}$ ) to confirm the role of IL in quinaldine ATH. Under the same reaction conditions, a TOF value of $60 \mathrm{~h}^{-1}$ was achieved with SBA-TsDPEN $20-\mathrm{ILBF}_{4}-\mathrm{Rh}$ (Table 2, entry 11), which is higher than that of

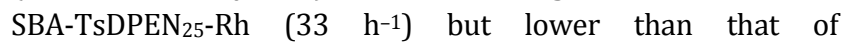
$\mathrm{SBA}_{\mathrm{ILBF}}-\mathrm{TsDPEN}_{50}-\mathrm{Rh}$. The above results confirm the acceleration effect of ILs and the advantage of ILs and TsDPEN in close proximity. In view of the tri-phase nature of quinaldine ATH, the IL linkage within the chiral solid catalyst may act as a phase transfer reagent for enriching the oil substrate and formate and facilitate hydride transfer, promoting the catalytic activity of the solid chiral catalyst.

\subsection{Substrate scope and recycling stability}

In addition to quinaldine, SBA-ILBF 4 -TsDPEN 50 - Rh could also catalyze a range of quinoline derivatives with good-to-moderate conversions and ee values. The alkyl substituent chain length within the quinoline derivatives had a slight influence on the ee values (Table 3, entries 1-5). With electron-rich substituents at the 6-position, 87\% conversion with $94 \%$ ee was obtained (Table 3, entry 1). For the 2-pentyl-substituted substrate, the conversion decreased to $79 \%$ (Table 3, entry 5), ascribed to the steric hindrance of the substituent. The electron-deficient substituents like - $\mathrm{F}$ or $-\mathrm{Br}$ at the 6-position caused decreasing conversion to $80 \%$ and $83 \%$, respectively; however, high ee values could still be obtained (Table 3, entries 6 and 7). These results show that the chiral solid catalysts have a relatively wide substrate scope.

The stability of the solid chiral catalysts was investigated

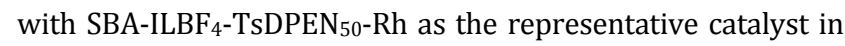
quinaldine ATH. The hot filtration test was performed to confirm that the ATH reaction was catalyzed by the solid catalyst. After the solid catalyst was removed after $1 \mathrm{~h}$ reaction by filtration, the filtrate was allowed to react for another $11 \mathrm{~h}$. No notable increase in conversion was observed (Fig. 4(b)), indicating that the reaction was catalyzed by the solid catalyst. Furthermore, the solid catalyst can be easily recycled at least 5 times without a marked loss of enantioselectivity, though a prolonged reaction time is required. ICP analysis of the reaction filtrate showed that approximately $0.72 \%$ of Rh leached after 5 cycles. The FT-IR spectrum of the reused catalyst was almost identical

Table 3

Asymmetric transfer hydrogenation of substituted quinoline derivatives with SBA-ILBF 4 -TsDPEN50-Rh a.

\begin{tabular}{|c|c|c|c|c|}
\hline Entry & $\mathrm{R}^{1}$ & $\mathrm{R}^{2}$ & Conversion $^{\mathrm{b}}(\%)$ & $e e^{\mathrm{c}}(\%)$ \\
\hline 1 & $\mathrm{Me}$ & $\mathrm{Me}$ & 87 & 94 \\
\hline $2^{d}$ & $\mathrm{H}$ & Et & 89 & 90 \\
\hline $3^{d}$ & $\mathrm{H}$ & $n-\mathrm{Pr}$ & 87 & 90 \\
\hline $4^{d}$ & $\mathrm{H}$ & $n-\mathrm{Bu}$ & 88 & 90 \\
\hline $5^{d}$ & $\mathrm{H}$ & $n$-Pentyl & 79 & 89 \\
\hline 6 & $\mathrm{~F}$ & $\mathrm{Me}$ & 80 & 90 \\
\hline $7 \mathrm{e}$ & $\mathrm{Br}$ & $\mathrm{Me}$ & 83 & 90 \\
\hline
\end{tabular}

a Reaction conditions: catalyst $(5 \mu \mathrm{mol} \mathrm{Rh})$, substrate $(0.5 \mathrm{mmol})$, $\mathrm{HCOONa} \cdot 2 \mathrm{H}_{2} \mathrm{O}(520 \mathrm{mg}, 5.0 \mathrm{mmol})$, and $5.0 \mathrm{~mL}$ buffer $(\mathrm{pH}=5.0,4 \mathrm{M}$ HOAc-NaOAc), $40{ }^{\circ} \mathrm{C}, 12 \mathrm{~h}$. ${ }^{\mathrm{b}}$ The conversion was determined using GC. ${ }^{\mathrm{c}}$ The ee value was determined using HPLC. ${ }^{\mathrm{d}}$ Reactions were performed on a $0.25 \mathrm{mmol}$ scale. ${ }^{\mathrm{e}} 0.3 \mathrm{~mL}$ of EtOAc was added to the reaction. 


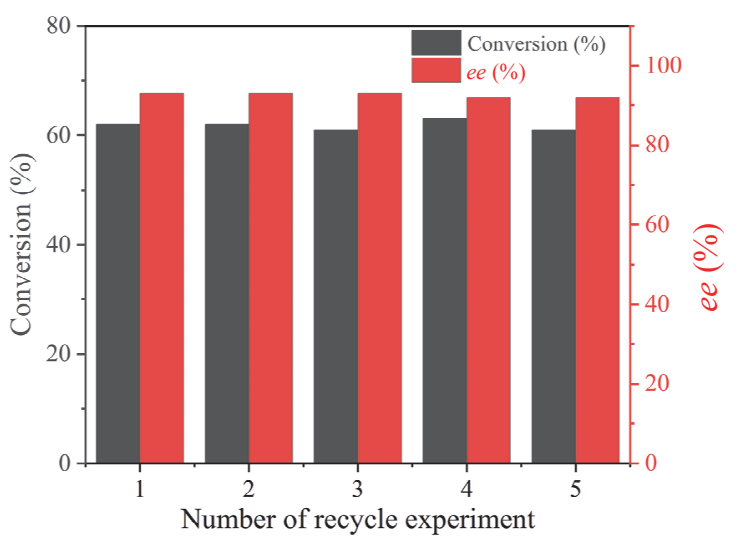

Fig. 5. Recyclability of $\mathrm{SBA}_{-} \mathrm{ILBF}_{4}-\mathrm{TSDPEN}_{50}-\mathrm{Rh}$ in the asymmetric transfer hydrogenation of quinaldine (the reaction times for cycles 1,2 , 3,4 , and 5 are $2,2,3,6$, and $12 \mathrm{~h}$, respectively).

to that of the fresh catalyst; the characteristic peaks at 1160 $\mathrm{cm}^{-1}$, corresponding to the stretching peak of $\mathrm{S}=0$, could be clearly observed, indicating the stability of the immobilized chiral ligands (Fig. S6(a)). The TEM image of the reused catalyst confirmed the hexagonal mesoporous structure was well maintained and no metal NPs were observed, suggesting no decomposition of immobilized chiral metal complexes to nanoparticles (Fig. S6(b)). Therefore, the chiral solid catalyst synthesized using the one-pot method is robust. The slight decrease in the activity might be attributed to the deterioration of Rh complex by oxygen during recycling.

\section{Conclusions}

In summary, we developed a one-pot method for the immobilization of the Noyori-Ikariya catalyst using IL linkage for the ATH of quinoline derivatives. FT-IR, ${ }^{13} \mathrm{C}$ CP/TOSS, TGA, and $\mathrm{N}_{2}$ sorption results confirmed the successful grafting of the chiral ligand into the SBA-15 mesopores. Elemental analysis, together with UV-Vis results, showed that approximately $52 \%-62 \%$ of

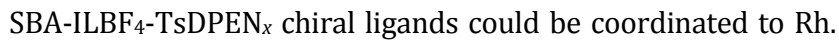

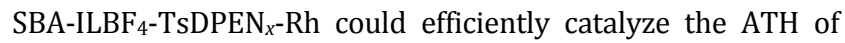

quinolines with HCOONa as the hydrogen source in a buffer solution. The increase in $\mathrm{pH}$ value of the reaction system caused reaction rate retardation, which could be solved by increasing the buffer solution concentration or the injection of HCOOH. The IL linkages near the chiral active sites endowed the solid catalysts with the phase transfer feature. In comparison with its homogeneous counterpart, the solid catalyst with IL linkage showed even higher activity, though there was a slight decrease in the ee value (91\% vs. 95\%) under identical conditions, which was more active than that with the alkane linkage $\left(93 \mathrm{~h}^{-1}\right.$ vs. $\left.33 \mathrm{~h}^{-1}\right)$. This one-pot immobilization method could be applied to the construction of other heterogeneous catalysts, using IL linkage for aqueous asymmetric reactions.

\section{Electronic supporting information}

Supporting information is available in the online version of this article.

\section{References}

[1] I. Muthukrishnan, V. Sridharan, J. C. Menendez, Chem. Rev., 2019, 119, 5057-5191.

[2] V. Sridharan, P. A. Suryavanshi, J. C. Menendez, Chem. Rev., 2011, 111, 7157-7259.

[3] D.-S. Wang, Q.-A. Chen, S.-M. Lu, Y.-G. Zhou, Chem. Rev., 2012, 112, 2557-2590.

[4] Y.-E. Luo, Y.-M. He, Q.-H. Fan, Chem. Rec., 2016, 16, 2693-2707.

[5] W.-B. Wang, S.-M. Lu, P.-Y. Yang, X.-W. Han, Y.-G. Zhou, J. Am. Chem. Soc., 2003, 125, 10536-10537.

[6] T. Wang, L.-G. Zhuo, Z. Li, F. Chen, Z. Ding, Y. He, Q.-H. Fan, J. Xiang, Z.-X. Yu, A. S. C. Chan, J. Am. Chem. Soc., 2011, 133, 9878-9891.

[7] H. Zhou, Z. Li, Z. Wang, T. Wang, L. Xu, Y. He, Q.-H. Fan, J. Pan, L. Gu, A. S. C. Chan, Angew. Chem. Int. Ed., 2008, 47, 8464-8467.

[8] M. Rueping, A. P. Antonchick, T. Theissmann, Angew. Chem. Int. Ed., 2006, 45, 3683-3686.

[9] D.-W. Wang, W. Zeng, Y.-G. Zhou, Tetrahedron: Asymmetry, 2007, 18, 1103-1107.

[10] C. Wang, C. Li, X. Wu, A. Pettman, J. Xiao, Angew. Chem. Int. Ed., 2009, 48, 6524-6528.

[11] V. Parekh, J. A. Ramsden, M. Wills, Tetrahedron: Asymmetry, 2010,

\section{Graphical Abstract}

Chin. J. Catal., 2021, 42: 1576-1585 doi: 10.1016/S1872-2067(20)63764-0

\section{Development of efficient solid chiral catalysts with designable linkage for asymmetric transfer hydrogenation of quinoline derivatives}

Yiqi Ren, Lin Tao, Chunzhi Li, Sanjeevi Jayakumar, He Li, Qihua Yang* Dalian Institute of Chemical Physics, Chinese Academy of Sciences; University of Chinese Academy of Sciences

A new solid chiral catalyst with a designable linkage was developed. SBA-ILBF 4 -TsDPEN-Rh, containing an IL linkage, could catalyze the asymmetric transfer hydrogenation of quinaldine with $93 \mathrm{~h}^{-1}$ TOF and $93 \%$ ee.

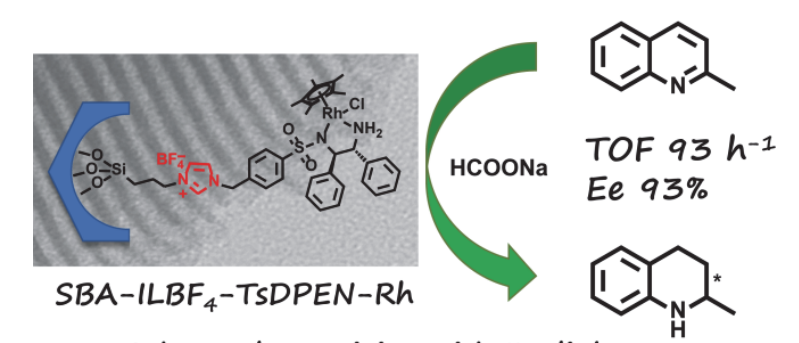

Enhanced reactivity with ILs linkage 
21, 1549-1556.

[12] Q.-S. Guo, D.-M. Du, J. Xu, Angew. Chem. Int. Ed., 2008, 47, 759-762.

[13] R. Noyori, S. Hashiguchi, Acc. Chem. Res., 1997, 30, 97-102.

[14] Q.-H. Fan, Y.-M. Li, A. S. C. Chan, Chem. Rev., 2002, 102, 3385-3466.

[15] M. Heitbaum, F. Glorius, I. Escher, Angew. Chem. Int. Ed., 2006, 45, 4732-4762.

[16] D. Zhao, K. Ding, ACS Catal., 2013, 3, 928-944.

[17] R. Liu, T. Cheng, L. Kong, C. Chen, G. Liu, H. Li, J. Catal., 2013, 307, 55-61.

[18] X. Zhang, Y. Zhao, J. Peng, Q. Yang, Green Chem., 2015, 17, 1899-1906.

[19] X. Shu, R. Jin, Z. Zhao, T. Cheng, G. Liu, Chem. Commun., 2018, 54, 13244-13247.

[20] F. Zhou, X. Hu, M. Gao, T. Cheng, G. Liu, Green Chem., 2016, 18, 5651-5657.

[21] S. Bai, H. Yang, P. Wang, J. Gao, B. Li, Q. Yang, C. Li, Chem. Commun., 2010, 46, 8145-8147.
[22] T. Takeda, M. Terada, J. Am. Chem. Soc., 2013, 135, 15306-15309.

[23] G. Kang, S. Lin, A. Shiwakoti, B. Ni, Catal. Commun., 2014, 57, 111-114.

[24] P. N. Liu, P. M. Gu, F. Wang, Y. Q. Tu, Org. Lett., 2004, 6, 169-172.

[25] S. Jayakumar, H. Li, L. Tao, C. Li, L. Liu, J. Chen, Q. Yang, ACS Sustain. Chem. Eng., 2018, 6, 9237-9245.

[26] J. C. Lassegues, J. Grondin, D. Cavagnat, P. Johansson, J. Phys. Chem. A, 2009, 113, 6419-6421.

[27] L. Tao, C. Li, Y. Ren, H. Li, J. Chen, Q. Yang, Chin. J. Catal., 2019, 40, 1548-1556.

[28] L. Tao, Y. Ren, C. Li, H. Li, J. Liu, Q. Yang, Asian J. Org. Chem., 2020, 9, 1623-1630.

[29] L. Tao, Y. Ren, C. Li, H. Li, X. Chen, L. Liu, Q. Yang, ACS Catal., 2020, 10, 1783-1791.

[30] D. Zhao, J. Feng, Q. Huo, N. Melosh, G. H. Fredrickson, B. F. Chmelka, G. D. Stucky, Science, 1998, 279, 548-552.

\title{
喹啉及其衍生物的多相不对称氢转移反应
}

\author{
任亦起 ${ }^{\mathrm{a}, \mathrm{b}}$, 陶 琳 ${ }^{\mathrm{a}, \mathrm{b}}$, 李纯志 ${ }^{\mathrm{a}, \mathrm{b}}$, Sanjeevi Jayakumar ${ }^{\mathrm{a}}$, 李 贺 ${ }^{\mathrm{a}}$, 杨启华 ${ }^{\mathrm{a}, *}$ \\ ${ }^{\mathrm{a}}$ 中国科学院大连化学物理研究所催化基础国家重点实验室, 辽宁大连 116023 \\ b 中国科学院大学, 北京100049
}

摘要: 喹啉及其衍生物的多相不对称氢转移是制备杂环手性化合物的理想策略. 多相手性催化体系具有催化剂可循环利 用及产物分离提纯容易等优势. 然而, 喹啉及其衍生物的多相手性高效催化体系鲜有报道. 这主要是由于多相手性氢转移 为水-油-固三相反应, 在反应的过程中, 传质问题极大影响固体催化剂的催化性能. 因此, 发展具有相转移功能的手性催化 材料, 是提高多相氢转移体系催化效率的有效途径.

本文采用一锅法合成策略, 通过离子液体(ILs)为连接基团实现了 TsDPEN手性配体在SBA-15介孔孔道中的嫁接. 与 $R h$ 盐配位后, 获得手性固体催化剂SBA-ILBF 4 -TsDPEN-Rh. FI-IR光谱和 ${ }^{13} \mathrm{C} N M R$ 结果表明, 手性催化活性中心成功负载在 SBA-15中, 随着手性活性中心负载量的增加, SBA-ILBF 4 -TsDPEN-Rh的比表面积、孔径和孔容逐渐降低. 在喹啉衍生物不

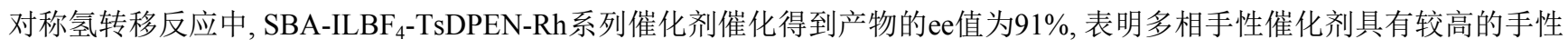
选择性. 多相手性催化剂的催化活性随着活性中心负载量的上升而呈现下降的趋势, 这主要是由于活性中心负载量较低 的多相催化剂具有更高的比表面积和孔容, 更有利于催化过程中的传质. 与均相手性催化剂相比, 优化后的多相手性催化 剂表现出更高的催化活性 (TOF 值分别为 75 和 $92 \mathrm{~h}^{-1}$ ). 作为对比, 本文还合成了采用烷基链为连接基团的 SBA-TsDPEN ${ }_{25}-\mathrm{Rh}$, 并以其为基础进一步嫁接了 ILs 基团, 得到 SBA-TsDPEN $20-\mathrm{ILBF}_{4}-\mathrm{Rh}$. 在相同的反应条件下, $\mathrm{SBA} \mathrm{ILBF}_{4}-\mathrm{TsDPEN}_{50}-\mathrm{Rh}$ 表现出更高的催化活性. 上述结果证实了 ILs基团在反应过程中起到相转移以及富集氢源甲酸盐 的作用, 极大促进了喹哪啶不对称氢转移多相催化体系的活性, 并且ILs基团和手性活性中心在空间距离上的接近更有利 于催化活性的提高.

此外, 本文还研究了反应体系 $\mathrm{pH}$ 值对固体催化剂上反应速率的影响, 随着反应的进行, 反应溶液的 $\mathrm{pH}$ 会呈现明显上升 的趋势, 导致反应速率减缓以及底物转化受限. 通过在反应过程中加入适量甲酸或者选用浓度更高的缓冲溶液可以有效 防止催化过程中反应速率的减慢.

综上可见, 负载手性催化剂中的连接基团对多相手性催化剂的催化性能有重要影响. 通过改变手性配体的连接基团 提高手性固体催化剂的催化活性和手性选择性的策略可以拓展到其他多相手性催化体系.

关键词: 多相手性催化; 不对称氢转移; 喹啉衍生物; 咪唑盐; 离子液体; $N$-(对甲苯磺酰基)-1,2-二苯基乙二胺

收稿日期: 2020-12-18. 接受日期: 2021-01-18. 上网时间: 2021-05-05.

*通讯联系人. 电话: (0411) 84379552; 传真: (0411)84694447; 电子信箱: yangqh@dicp.ac.cn

基金来源：国家重点研发计划(2017YFB0702800); 国家自然科学基金重点项目(21733009, 21972134); 中国科学院战略性科技先 导专项(XDB17020200).

本文的电子版全文由Elsevier出版社在ScienceDirect上出版(http://www.sciencedirect.com/journal/chinese-journal-of-catalysis). 